\title{
SZTUKA BŁĄDZENIA. KARLA ČAPKA I SÁNDORA MÁRAIEGO PODRÓŻE LITERACKIE
}

\author{
AGNIESZKA JANIEC-NYITRAI ${ }^{1}$ \\ (Nitra-Budapeszt)
}

\begin{abstract}
Słowa klucze: podróże literackie, przestrzeń i miejsce w literaturze, poetyka przestrzeni
\end{abstract}
Key words: travelogues, space and place in literature, poetics of space

\begin{abstract}
Abstrakt: Agnieszka Janiec-Nyitrai, SZTUKA BŁĄDZENIA. KARLA ČAPKA I SÁNDORA MÁRAIEGO PODRÓŻE LITERACKIE. „PORÓWNANIA” 11, 2012, Vol. XI, ss. 265-276, ISSN 1733-165X. Artykuł poświęcony jest filozofii podróżowania i poznawania przestrzeni zarysowanym w tekstach podróżniczych Karla Čapka (Listy z podróży) i Sándora Máraiego (W podróży). Kluczowymi kwestiami poruszanymi $\mathrm{w}$ artykule są bunt przeciwko masowości przeżycia, poszukiwanie nowego spojrzenia na świat, protest przeciwko bezmyślnemu oglądaniu świata, a także, wyraźnie widoczna w tekstach obu pisarzy, niechęć do banalizacji procesu poznawczego, który powinien być pojmowany jako aktywny i twórczy stosunek do poznawanej rzeczywistości.
\end{abstract}

Abstract: Agnieszka Janiec-Nyitrai, THE ART OF BLUNDERING. THE LITERARY TRAVELS OF KARL ČAPEK AND SÁNDOR MÁRAI. “PORÓWNANIA" 11, 2012, Vol. XI, pp. 265-276, ISSN 1733-165X. The article is dedicated to the philosophy of travelling and discovering spaces depicted in the travelling literature of Karl Čapek (Letters from a journey) and Sándor Márai (While travelling). The key aspects in the texts include the rebellion against the mass experience, searching for a new perspective, protest against a careless outlook, but also, an unwillingness to trivialise the cognitive process, which should be understood as an active and creative attitude towards the reality which one gets to know, vividly visible in the texts of both authors.

Pomimo, że Karel Čapek i Sándor Márai należą do tej samej generacji środkowoeuropejskich pisarzy i urodzili się formalnie w tym samym państwie (AustroWęgry), funkcjonują dziś w czeskiej i węgierskiej świadomości literackiej w odmienny sposób. Nieco inna jest także recepcja ich twórczości w Polsce. Spowodo-

\footnotetext{
${ }^{1}$ Correspondence Address: janiec.nyitrai@gmail.com
} 
wane jest to różnymi losami samych autorów, odmiennym charakterem ich spuścizny literackiej, a także - a może przede wszystkim - inną oceną ich artystycznych dokonań. Porównywanie wybranych aspektów ich utworów wydaje się jednak uzasadnione, ponieważ analiza konfrontatywna pozwala lepiej zrozumieć specyfikę twórczości obu pisarzy².

Starszy o dziesięć lat Čapek był przedstawicielem i jednym z ojców młodej czeskiej demokracji okresu Pierwszej Republiki. Świat czeskiego pisarza zaczął się formować po I wojnie światowej. Tymczasem dla Máraiego właśnie I wojna światowa przyniosła rozpad jego ojczyzny - monarchii habsburskiej, a tym samym położyła kres wykwintnego świata mieszczańskiego, którego był reprezentantem. Čapek nie dożył końca „swego świata”, który przyniosła II wojna światowa i poznał tylko przedsmak rozkładu wartości, które sam reprezentował, natomiast węgierskiemu pisarzowi dane było boleśnie doświadczyć niemal wszystkich traum XX wieku - straty ukochanego miasta rodzinnego, które zostało przemianowane z Kassa na Košice i znalazło się w granicach Czechosłowacji, oblężenia Budapesztu, wysadzenia w powietrze jego domu, wkroczenia Armii Czerwonej i zaprowadzania nowego komunistycznego ładu, aż w końcu goryczy emigracji. Márai stał się symbolem odchodzącego bezpowrotnie świata mieszczańskich tradycji, jednym z ostatnich dokumentatorów, afirmatorów, ale także krytyków dziedzictwa monarchii, Čapek natomiast może być postrzegany jako symbol demokratycznych przemian w Europie Środkowej okresu międzywojennego.

Odrębność ich losów odzwierciedla w oczywisty sposób tematyka twórczości: Márai, sierota po imperium, portretował człowieka na rozdrożu, podczas gdy czeskiego pisarza interesowała przede wszystkim znajdująca się na rozdrożu ludzkość. Dramaty uchwycone w powieściach Máraiego są kameralne, rozgrywają się ukradkiem, pozbawione świateł reflektorów są dalekie od emocjonalnego ekshibicjonizmu. Márai śledzi je z dystansu chłodnym wzrokiem człowieka, który sam stracił już niemal wszystko. Jest kronikarzem, a nie uczestnikiem okrutnego teatru świata. Właśnie to okrucieństwo losu pociągało węgierskiego pisarza najbardziej: „Z ludźmi potrafię być solidarny jedynie w chwilach, kiedy przeżywają tragedię; ich idylla pozostawia mnie obojętnym i najchętniej bym ją pominął" 3 . Čapek swoją twórczością stawiał sam siebie w pozycji rzecznika ludzkości, wierzył w siłę demokratycznych ideałów, ostrzegał przed groźbą faszyzmu, komunizmu, przed zagrożeniem kultury mechanizacją i technicyzacją świata. Projekcje literackie Čap-

2 Próbę taką podjęła M. Pató w dwu komparatystycznych artykułach poświęconych kwestii obrazu dzieciństwa i mieszczaństwa u obu autorów. Zob. M. Pató, Dětství jako obraz ztracené měštanské idyly (připad Karla Čapka a Sándora Máraiho), w: Od početí ke školní brašně. Sborník z odborného semináre konaného 29. - 30. května 2008 ve Východočeském muzeu v Pardubicích. Red. M. Halířová. Pardubice 2008, s. 165-178; M. Pató, Sándor Márai i Karel Čapek - autorzy prozy mieszczańskiej? w: Procesy autoidentyfikacji na obszarze kultur środkowoeuropejskich po roku 1918. Red. J. Goszczyńska. Warszawa 2008, s. 338-352.

3 S. Márai, W podróży. Wybór i przekład T. Worowska. „Zeszyty Literackie”, Warszawa 2011, s. 86. 
ka skierowane były przede wszystkim na teraźniejszość i przyszłość, podczas gdy węgierski pisarz częściej patrzył w przeszłość i ostentacyjnie odwracał wzrok od beszczeszczonej teraźniejszości. Młodszy wiekiem Márai jawi się paradoksalnie, jako bardziej staroświecki, konserwatywny w swoich poglądach, typowy przedstawiciel dziewiętnastowiecznego mieszczaństwa. Čapek natomiast ze swoją wiarą w człowieka zdawał się reprezentować młodsze pokolenie.

Odmienne jest także miejsce ich twórczości we współczesnej świadomości literackiej. Čapek, przed wojną ceniony, czytany i silnie obecny w życiu kulturalnym Republiki, a następnie celowo zapominany, w latach sześćdziesiątych minionego stulecia został na nowo "odkryty" i był stopniowo przywracany do panteonu czeskiej literatury, oczywiście wybiórczo i z ideologicznie umotywowanym rozłożeniem akcentów. Dziś jego twórczość należy niewątpliwie do kanonu czeskiej literatury i wciąż są podejmowane próby odczytania jej na nowo przy pomocy nowych narzędzi ${ }^{4}$ czy zbadania szerszego wpływu na całą generację ${ }^{5}$, ponieważ twórczość Čapka wciąż nosi w sobie potencjał interpretacyjny.

Nieco inny los spotkał dzieła Máraiego. Po II wojnie światowej pisarz, który $\mathrm{w}$ latach trzydziestych minionego wieku święcił sukcesy literackie, został niemal zapomniany. Przypadł mu w udziale gorzki los emigranta oraz związane z nim przymusowe wykluczenie z życia literackiego na Węgrzech. Teresa Worowska, wybitna tłumaczka dzieł Máraiego na język polski, w posłowiu do jednej z jego najsłynniejszych powieści Wyznania patrycjusza nazwała go „wielkim nieznajomym”, ponieważ praktycznie aż do samobójczej śmierci pozostał w swojej ojczyźnie nieznany, a renesans jego twórczości zaczął się dopiero po roku 1989. Dziś Márai jest zaliczany do największych węgierskich pisarzy XX wieku. Nie słabnie zainteresowanie fenomenem twórczości Máraiego wśród historyków literatury ${ }^{7}$ a spuścizna literacka pisarza wciąż pozostaje atrakcyjna dla współczesnego czytelnika i widza, o czym świadczy fakt, iż podlega ona ciągłym artystycznym aktualizacjom ${ }^{8}$.

Zwierciadlanym odbiciem sytuacji na Węgrzech i w Czechach jest status obu autorów w Polsce. W ciągu ostatnich kilku lat można zaobserwować niebywały wzrost zainteresowania pisarstwem Máraiego - w prestiżowych wydawnictwach

${ }^{4}$ Warto wspomnieć chociażby artykuł D. Mocnej Čapki̊v Krakatit - předzvěst postmoderny? „Tvar" 1994, nr 2, s. 6-7 czy J. Hrabala K recepci Čapkova Foltýna: Omyly v předpokladech a cílech interpretace narationí literatury. "Acta Universitatis Palackianae Olomucensis. Facultas Philosophica. Moravica" 2006 , t. 6, s. 87-97.

${ }^{5}$ Zob. M. Tichý, Kritické dílo čapkovské generace. Opava 2009.

${ }^{6}$ T. Worowska, Wielki nieznajomy, w: S. Márai, Wyznania patrycjusza. Przeł. T. Worowska. Warszawa 2005, s. 497.

7 Wystarczy wspomnieć monografię Lászlóa Rónayego Sándor Márai. Budapest 2005 albo publikację Istvána Frieda Író esóköpenyben. Márai életének, pályájának emlékezete. Budapest 2007.

8 Szerokim echem wśród widzów i krytyków odbił się kameralny obraz Eszter hagyatéka w reżyserii Józsefa Siposa z 2008. 
jak "Czytelnik" czy „Zeszyty Literackie” publikowane są tłumaczenia jego utworów, polskie teatry wystawiają sztuki na podstawie jego prozy ${ }^{9}$, powstają także interesujące prace dotyczące jego twórczości ${ }^{10}$. Karel Čapek uznawany jest przede wszystkim za klasyka literatury czeskiej, jednakże jego utwory cieszą się uznaniem głównie wąskiego kręgu bohemistów, choć w ostatnim czasie można także zanotować wzmożone zainteresowania jego twórczością ${ }^{11}$.

Wpływ na zainteresowanie pisarstwem obu autorów mają niewątpliwie pozycje, które w niewielkim odstępstwie czasu ukazały się niedawno na polskim rynku wydawniczym, o podobnie brzmiących tytułach i zbliżonej tematyce: Čapka Listy $z$ podróży ${ }^{12}$ i Máraiego $W$ podróży ${ }^{13}$. Pomimo iż trajektorie ich pisarstwa, jak już zasygnalizowałam wcześniej, rzadko się przecinały, w przypadku działalności dziennikarskiej, w tym szczególnie podróżniczopisarskiej, jest inaczej, zwłaszcza jeśli chodzi o poruszaną tematykę, formę czy przesłanie. Poprzez zestawienie ze sobą dwóch odrębnych tekstów postaram się nakreślić istotę ars apodemica obu autorów, koncentrując się przede wszystkim na tym, co oba utwory łączy. W artykule podejmuję problematykę przestrzeni jako inspiracji i impulsu potrzebnego do „podróży w głąb siebie”, poruszam kwestię noetycznego wymiaru podróżowania i próbuję określić, jakie pytania rodzi poznawanie nieznanej przestrzeni. Przeanalizuje przede wszystkim eseje i felietony z podróży po Italii. Artykuł mój można także uznać za swego rodzaju protest przeciwko zaszufladkowaniu esejów podróżniczych Máraiego i Čapka wyłącznie jako urzekającego i staroświeckiego świadectwa międzywojennej świadomości ${ }^{14}$, ponieważ teksty te przynoszą według mnie daleko głębszą refleksję o człowieku i jego stosunku do poznawanej przestrzeni, są odzwierciedleniem określonego klimatu intelektualnego i pod wieloma względami można je uznać za nowatorskie, bowiem uwrażliwiają na kierunek przemian kultury, przestrzeni i samego człowieka, który współcześnie doświadczamy.

${ }^{9}$ Np. Żar w Teatrze Narodowym w Warszawie w reżyserii E. Wojtaszka, Przygoda w Teatrze Polonia w reżyserii K. Jandy, Dziedzictwo Estery w toruńskim Teatrze im. W. Horzycy, Czary Mary i Lala, czyli pierwsza miłość w reżyserii A. Piszczatowskiego w Teatrze Polskiego Radia.

${ }^{10}$ Zob. W. Bolecki, Exile Diaries: Sándor Márai, Gustaw Herling-Grudziński and Others. Eight Issues of Comparison. Exile Autobiographical Exile Writing, w: The Exile and Return of Writers from East-Central Europe. A Compendium. Red. J. Neubauer, B. Zs. Török. Berlin - New York 2009, s. 422-431. Zob. M. Szladowski, "Starzenie obserwuję w sobie, na sobie tak, jak coś w rodzaju przygody“. Starość Sándora Máraiego. w: Egzystencjalne doświadczenie starości w literaturze. Red. A. Gleń, I. Jokiel, M. Szladowski. Opole 2008, s. 49-56.

${ }^{11} \mathrm{~Np}$. poświęcona braciom Čapkom Międzynarodowa Noc Literatury organizowana w Warszawie przez Czeskie Centrum 25-26 maja 2012 roku.

12 K. Čapek, Listy z podróży. Przeł. P. Godlewski. Wyd. W.A.B. Warszawa 2011, s.s. 572.

13 S. Márai, W podróży. Przeł. T. Worowska. Warszawa 2011, ss. 204.

${ }_{14}$ Zob. K. Cieślik, Wędrowiec z wyboru. (recenzja książki: S. Márai, „W podróży”). „Polityka” 2012, nr 2843, s. 64. 
Jednym z wyraźnych pomostów łączących teksty podróżnicze obu autorów jest dominujące przeświadczenie o konieczności zejścia z utartych szlaków, świadomy wybór peryferii jako fenomenu, który pozwoli otworzyć się na nowe doświadczenia i mówi więcej o poznawanej przestrzeni niż o centrum. U Čapka mamy do czynienia przede wszystkim z klasycznymi peryferiami przestrzennymi, Márai wybiera częściej peryferia temporalne. Čapek, oprócz dryfowania po otwartym morzu peryferii, nie stroni także od portów-punktów centralnych. Inaczej jest u Máraiego, który zdaje się celowo omijać rafy i mielizny miejsc znanych i po tysiąckroć opisywanych. Nie ulega jednak wątpliwości, że obu pisarzy przyciągają terytoria drugoplanowe. Czym podyktowany jest ów wybór? Możemy dopatrywać się tu fenomenu, który Elżbieta Rybicka nazywa „decentralizacją mapy"15, a tym samym obu autorów można uznać za prekursorów zmian, których doświadczamy $\mathrm{w}$ epoce ponowoczesnej. Centrum jawi się jako miejsce, w którym dochodzi do zagęszczenia pewnych cech i zjawisk. Jest to esencja rzeczywistości, która została już wielokrotnie zinterpretowana i nasycona sensami. Jest to również miejsce na swój sposób martwe, bo już dokonane i dokończone. Przestrzeń centrum tworzą zjawiska, ale nade wszystko interpretacje tych zjawisk. Ciasno spleciona sieć interpretacji, odnośników, piramida palimpsestów, ustosunkowań, cytatów i analogii uniemożliwia zanurzenie się pod powierzchnię zjawisk i zobaczenie ich innych wymiarów. Konkretne fenomeny stanowiące kwintesencję „angielskości”, „włoskości” itd., były już tylekroć opisywane, analizowane, że nie są już atrakcyjne poznawczo i nie stanowią artystycznego wyzwania dla obu pisarzy. Nadają się tylko do fotografowania, do obiektywnego, nietwórczego powielania, schematycznego opisu i „kopiowania”, a tym samym nie można ich uznać za interesujący przedmiot badań.

Dychotomia centrum/peryferie zyskuje w tekstach obu pisarzy nowy wymiar związany ze stosunkiem do człowieka. To właśnie jednostka ludzka, pojedynczy człowiek, jako peryferyjna część ogółu, budzi zainteresowanie i podziw. Świadectwem tego są słowa Máraiego:

Poddałem się ludziom i tylko oni tak naprawdę mnie interesują, pejzaże, egzotyka opadają ze mnie jak liście, sklepik piekarza z Palermo bardziej mnie niepokoi niż tamtejsze muzeum, a tych kilka osób, które sobie wybrałem i chciałbym odkryć, zbadać i poznać, zajmuje mnie daleko bardziej niż kontynenty i cały świat ${ }^{16}$.

Čapka zachwyca sztuka, w której widać błędy będące świadectwem indywidualności człowieka17. Na drugim biegunie znajduje się bezlitośnie wyśmiewana

${ }^{15}$ E. Rybicka, Geopoetyka (o mieście, przestrzeni i miejscu we wspótczesnych teoriach i praktykach kulturowych,w: Kulturowa teoria literatury. Główne pojęcia i problemy. Red. M. P. Markowski, R. Nycz. Kraków 2006, s. 481.

${ }^{16}$ S. Márai, op. cit., s. 74.

17 Zob. K. Čapek, op. cit., s. 64-65. 
przez obu pisarzy stadność przeżycia, miałkość powierzchownego poznania typowa dla ludzi przeciętnych. Čapek i Márai pielęgnują w sobie obcość, jednostkowość przeżycia, unikalność doświadczenia. Owa dobrowolna atopia, arystokratyczność postrzegania świata gwarantuje ekskluzywność poznania. Jest to pragnienie na wskroś nowoczesne, ponieważ atopia, jak ją opisuje Adam Dziadek, jest typowa dla społeczeństwa ponowoczesnego:

Doświadczenie atopii łączy się z marzeniem: żyć we wspólnocie i jednocześnie nie dać się usidlić, zachować niezależność poza konwencjami [...] Oddzielić się od ewidentnej, łatwo postrzegalnej głupoty zbiorowości, która przytłacza, tłamsi, gwałci, zmusza do uległości, jakąś niewidzialną siłą przyszpila do miejsca wspólnego, udaremnia jednostkowość i niepowtarzalność ${ }^{18}$.

Čapek i Márai pragną uniknąć właśnie owej zbiorowej ekstazy nad dziełem oznaczonym w przewodniku gwiazdką i wolą zejść na manowce poszukiwań niepewnej prawdy i nieoczywistego piękna. Dla obu pisarzy może to być także ucieczka przed wszechogarniającą intertekstualnością, przed przytłaczającym palimpsestem ważnych tekstów kultury, które wrosły w poznawaną i doświadczaną przez nich przestrzeń. Jest to także ucieczka przed przymusem ciągłego ustosunkowywania się do wcześniejszych wypowiedzi, którymi oplecione jest centrum.

Peryferie nie są w znaczeniu przestrzennym oddalone od centrum, znajdować się mogą w samym środku poznawanej przestrzeni, ale kryją się jakby pod dekoracją, kurtyną przykrywającą centrum. Obu pisarzy interesuje właśnie to, co znajduje się za kolorową rekwizytornią, za malowniczością i wyświechtanymi interpretacjami. U Čapka są to krzywe uliczki, gdzie zatrzymał się czas, duszne korytarze włoskich domów, małe kościółki, przytłoczone przez wielkie katedry, obrazy naiwnych malarzy, "sztuka nieumiejętna”, nieskażona doskonałością, u Máraiego kurorty po sezonie czy dworzec w Wenecji nad ranem. W przestrzeni peryferyjnej i czasie peryferyjnym punkty istotne są rozrzedzone i trzeba wykazać się inicjatywą, by je odnaleźć. Čapek i Márai są wyczuleni na każdy przejaw teatralizacji życia, na sztuczne dodawanie malowniczości i barwności, z którymi często spotykają się na swojej drodze. San Marco przypomina Čapkowi orkiestron, maszynerię, która gra, niczym katarynka po wrzuceniu monety ${ }^{19}$, Márai patrzy krytycznie na krajobrazy przesadnie urokliwe i przypominające dekoracje opero$w^{20}$, ale pełnym miłości wzrokiem spogląda na Wenecję o czwartej nad ranem, Wenecję, która ,"[...]wygląda teraz jak scena teatralna po skończonych występach, której jeszcze nie uporządkowano i nie pozamiatano ${ }^{21 " .}$

\footnotetext{
18 A. Dziadek, Atopia - stadność i jednostkowość. „Teksty Drugie” 2008, nr 1-2, s. 242-243.

${ }^{19}$ K. Čapek, op. cit., s. 9.

${ }^{20}$ S. Márai, op. cit., s. 74 .

${ }^{21}$ Ibidem, s. 101.
} 
Nieoczekiwanie otworzyła się przed Máraim okazja, by obejrzeć z innej perspektywy miasto, które, jak się wydawało, zna na wskroś, by przyjrzeć mu się, jak sam pisze, z nadscenia, skąd widać maszynerię, tylną stronę dekoracji i pajęczyny ${ }^{22}$. Nagle okazuje się, że miasto to nigdy nie było bardziej prawdziwe niż właśnie wtedy, pozbawione blasku i wreszcie nie zmuszane przez turystów do nieustannej ekstazy ${ }^{23}$. Čapek ocenia Wenecję podobnie, porównując ją do lunaparku: „[...] gdy pierwszy raz stanąłem na placu Świętego Marka, byłem kompletnie zbity z tropu i bardzo długo nie mogłem uwolnić się od przygnębiającego wrażenia, że nie jest to rzeczywiste, że to taki lunapark, gdzie ma się odbyć wenecka noc ${ }^{24 \prime}$. Niezwykle rzadko wraca dawno stracona niewinność Wenecji, choć Márai optymistycznie zauważa: „Jej piękno jest niezależne od widokówek, od par spędzających tu podróż poślubną i wspomnień, wieki nie zdołały jej zaślinić swoim lepkim entuzjazmem ${ }^{25}$.

Máraiego przyciąga także inny wymiar peryferyjności czasu. Tyrol wraz z odjazdem ostatniego turysty zaczyna żyć własnym życiem i staje się nagle mniej tyrolski niż zwykle. Sztucznie podkreślana ludowość okazuje się imitacją, skrupulatnie przygotowaną dla widzów.

Chata, która latem uchodziła za hotel, okazuje się zwykłą chłopską zagrodą, a jej przebrany na ludowo gospodarz, który w malowniczym stroju miał tworzyć węgierskim turystom iluzję tyrolskiego folkloru, jest naprawdę rolnikiem ${ }^{26}$.

Čapek w podobny sposób protestuje przeciwko „skansenyzacji” życia, której doświadczył w Holandii, gdzie "lud" dostaje zapomogi od państwa na ludowe stroje, pielęgnowanie tradycji i „,[...]mówi tutaj przede wszystkim po angielsku, niemiecku i francusku27"'.

Márai bardzo często stosuje metaforę centrum jako pierwszego planu, sceny, na której rozgrywa się przedstawienie, a ludzie - statyści i aktorzy - grają wyuczone role. W momencie, kiedy turysta-widz znika, opadają maski i ludzie wracają do normalnych zajęć: „W karczmach zamiast jodłujących grup śpiewaczych w barwnych tyrolskich strojach w soboty i niedziele wysiadują zmęczeni i apatyczni rolnicy ${ }^{28}$. Nawet pejzaż traci swoją odświętność i wygląda jak po rozsunięciu dekoracji29."

Čapek i Márai nie chcą chodzić utartymi ścieżkami, chcą błądzić, by odnaleźć wyjątkowość. Znane turystyczne atrakcje nie są dla obu pisarzy interesujące, ich

\footnotetext{
22 Zob. ibidem, s. 102.

23 Zob. ibidem, 103.

${ }^{24}$ K. Čapek, op. cit., s. 11.

25 S. Márai, op. cit., s. 96.

${ }^{26}$ Ibidem, s. 153.

${ }^{27}$ K. Čapek, op. cit., s. 328-329.

28 S. Márai, op. cit., s. 153.

${ }^{29}$ Zob. ibidem.
} 
znaczenie się zdewaluowało, doszło do proliferacji reprezentacji, co doprowadziło do inflacji znaczeń ${ }^{30}$. Wydaje się jednak, że decyzja dotycząca świadomego zejścia z utartych szlaków nie jest podyktowana wyłącznie chęcią jeszcze lepszego, dokładniejszego poznania przestrzeni, którą zdecydowali się odwiedzić. Przestrzeń poznawana jest tylko punktem wyjścia, impulsem, który wprawi w ruch wyobraźnię artysty i posłuży nie tylko poznawaniu świata, ale także poznawaniu siebie i innych ludzi. Jest to związane z osiągnięciem pewnej dojrzałości, o której pisze Márai otwarcie: „Z upływem czasu człowiek zaczyna podróżować także do własnego wnętrza, a wewnętrzny kompas pokazuje inne kierunki $31{ }^{\prime \prime}$. Zaskakująca jest niemal identyczna u obu artystów niechęć do bedekerów i jednoczesna afirmacja pozornie nic nie znaczącego szczegółu, który potrafi przyćmić najwspanialsze turystyczne atrakcje. Márai pisze:

Z antybedekera wędrowiec mógłby się nauczyć, że podczas podróży może się z lekkim sercem odnieść powierzchownie do znanych atrakcji, jeżeli pozostanie wystarczająco gorliwy i uważny wobec nieistotnych szczegółów. Może sobie nawet darować zachwyty i okrzyki w muzeach i katedrach, jeśli jednocześnie nie zapomni przyjrzeć się uważnie jakiejś klamce czy wystawie sklepu z żywnością. Pojąłby, że nic nie jest absolutnie istotne, jeśli postawimy to obok wagi rzeczy nieznacznych ${ }^{32}$. wiary:

U Čapka znajdziemy niemal identyczne wyznanie podróżniczej i noetycznej

Na tym świecie należy jednak widzieć wszystko: wszystko jest warte obejrzenia, każda ulica i każdy człowiek, każda rzecz marna oraz sławna. Nie ma niczego, co nie zasługiwałoby na zainteresowanie i zobaczenie ${ }^{33}$.

Status quo między istotnym a nieistotnym zostaje $\mathrm{w}$ ten sposób zachwiane i poddane $w$ wątpliwość, wszystko staje się godne zauważenia, a zbłądzenie zaczyna oznaczać wybawienie od nudy i ucieczkę od wyreżyserowanego na kartach przewodnika scenariusza. Ślepe podążanie za trasami naszpikowanymi atrakcjami turystycznymi czyni z człowieka "woła w wagonie podróżnym”, jak dosadnie wyraża się węgierski pisarz ${ }^{34}$. Bedeker ubezwłasnowolnia turystę, poddaje w wątpliwość istnienie własnej woli, sprawia, iż więcej uwagi poświęca opisowi zabytków, krajobrazów i dzieł sztuki, niż samym zabytkom, krajobrazom i dziełom sztuki ${ }^{35}$. Trzeba samemu sensualnie, przy pomocy wszystkim zmysłów zakosztować świata, co podkreśla czeski pisarz:

\footnotetext{
${ }^{30}$ E. Rybicka, op. cit., s. 485.

${ }^{31}$ S. Márai, op. cit., s. 74.

32 Ibidem, s. 94.

33 K. Čapek, op. cit., s. 8.

${ }^{34}$ Zob. S. Márai, op. cit., s. 94.

35 Zob. K. Čapek, op. cit., s. 20.
} 
Człowiek powinien by widzieć wszystko i wszystkiego dotknąć, tak jak poklepał tego osła w Toledo albo jak głaskał pień palmy w ogrodzie Alcázaru. Wszystkiego dotknąć choćby palcem. Cały świat przesunąć dłonią. To ci dopiero radość, człowieku, gdy widzisz lub dotykasz coś, czegoś dotychczas nie znał. Każda różnica w rzeczach i ludziach pomnaża życie ${ }^{36}$.

Poznanie za pomocą pośredników spłyca doznanie świata i czyni z człowieka nie podróżnika, ale oglądacza świata, dyletanta, który potrafi jedynie imitować świat. Podróżnik-dyletant nie potrafi przepuścić tego, co widzi przez soczewkę własnego wewnętrznego wzroku, widzi tylko to, co każą mu widzieć przewodniki i przewodnicy, boi się wybrać w samotną podróż, ponieważ prawdopodobnie nie będzie $\mathrm{w}$ stanie dostrzec niczego interesującego. Wynikiem takiego powierzchownego oglądania rzeczywistości, bez uruchomienia interakcji między człowiekiem i światem, są płaskie pocztówkowe impresje, które stanowią dowód na to, iż podróżnik-dyletant ślizga się jedynie po powierzchni rzeczywistości, nie ma wewnętrznej siły, by dostać się pod powierzchnię zjawisk. Stać go tylko na mechaniczne, fotograficzne utrwalanie tego, co widzi. Márai i Čapek sportretowali z przenikliwą ironią właśnie takich kopistów-dyletantów. Márai podczas podróży statkiem po Morzu Śródziemnym obserwował malarza, który bardzo sprawnie i technicznie poprawnie uwieczniał na akwarelach widoczki i krajobrazy: „Jego malunki mają swój urok, a jednak przechodzę obok niego kręcąc głową, bo wiem, że to, co dostrzega $\mathrm{i}$ jest $\mathrm{w}$ stanie $\mathrm{w}$ ten sposób uchwycić, to za mało ${ }^{37 \prime \prime}$. Malarzdyletant nie zadał sobie tyle trudu, by zejść na ląd, zanurzyć się w rzeczywistości, $\mathrm{w}$ świecie, który jest na wyciągnięcie ręki, nie potrafił aktywnie wdać się w dialog z tym, co widzi, i dlatego węgierski pisarz określa jego obrazy mianem starannie wyretuszowanych fotografii, które jednak pozostają puste, bo nie napełnia ich własna oryginalna artystyczna interpretacja. Jego opis świata nie zamienia się w sztukę, ponieważ nie potrafi zobaczyć rzeczy tak, jakby je widział po raz pierwszy, tak, aby stały się zupełnie nowe i obce, w myśl teorii Wiktora Szkłowskiego, który na przykładzie opisu konia u Tołstoja stosuje właśnie takie rozróżnienie między sztuką a nie-sztuką ${ }^{38}$. Zgrabne i technicznie doskonałe uwiecznianie w przyjemnej kolorystyce nie jest, jak podkreśla Márai, wystarczające ${ }^{39}$. Świat nabiera znaczeń i wyjątkowości dopiero w kontakcie z człowiekiem, wrażliwym interpretatorem ukrytych znaczeń, to człowiek ożywia potencjał piękna tkwiący w przestrzeni. Poza kartonową dekoracją barwnej widokówki drzemie świat czekający na odkrycie: „Istnieje inna rzeczywistość - odbicie, jakie świat pozostawia

36 Ibidem, s. 293.

37 S. Márai, op. cit., s. 79.

38 Zob. W. Szkłowski, Sztuka jako chwyt, w: Teoria badań literackich za granica. Antologia t. II, cz. III. Wybrała S. Skwarczyńska. Kraków 1986, s. 18-19.

39 Zob. S. Márai, op. cit., s. 79. 
w tobie, jeśli jesteś artystą40". Márai podaje nawet receptę na przeniknięcie do ukrytych czeluści świata: „[...] szczegóły trzeba zanurzyć w utrwalaczu pamięci, a potem w ogóle o wszystkim zapomnieć, by dopiero później, znacznie później nadać formę tym okruchom, które pozostały po trywialnych realiach ${ }^{41}$. Ucieczką od trywialności i schematyzmu recepcji świata może być właśnie zejście z utartych szlaków, które przy odrobienie szczęścia i dobrej woli, czyli aktywnego podejścia do poznawanej rzeczywistości, jest w stanie odblokować poznającego i otworzyć tkwiące w nim pokłady zwykłej ludzkiej ciekawości, pierwotnego, dziecięcego zachwytu nad światem i wyrwać z zaklętego kręgu bedekerów i turystycznych atrakcji. Kopiowanie świata poprzez utrwalanie rzeczywistości $\mathrm{w}$ formie zdjęć albo powierzchownego obrazu czyni z człowieka jedynie pseudo-artystę, który nie patrzy na świat jako na obiekt poznania, ale jako na obiekt do fotografowania. Čapek w podobny sposób drwi z bezrefleksyjności turystów, których nazywa kopistami. Zafrapowani jak najdokładniejszym oddaniem pejzażu lub skopiowaniem obrazu znanego mistrza nie zauważają, że ucieka im to, co najcenniejsze, ulotność chwili, naturalność, to, co odgrywa się poza dekoracją i zapiera oddech w piersiach:

Dzisiaj w Fiestole trzy naraz malowały klasztorny krużganek i cyprysy; parę kroków od nich tarzało się w trawie dziecko ze szczeniakiem, i było to tak piękne, że zapomniałem patrzeć na te marzycielskie krużganki [...] ale trzy kopistki z całą powagą nadal pacykowały swoje marzycielskie krużganki i cyprysy, i ani jedna nie zdjęła okularów, by spojrzeć na dziecko ze szczenięciem lub przetrzeć sobie oczy ${ }^{42}$.

Zbłądzenie, zejście z utartego szlaku to właśnie owo kluczowe „przetarcie oczu", spojrzenie na świat na nowo. Przewodniki, aparaty fotograficzne, pędzle, dają jedynie błędne poczucie odkrycia istoty świata, są tylko pewnego rodzaju "ułatwiaczami" w uchwyceniu jego rozmaitości, ale fenomeny te są martwe, bo nie żywi ich ludzka wyobraźnia, stają się bezosobowe i nic nieznaczące. „Świat mieści się w aparacie Kodaka, wspomnienia przesuwają się jak klatki filmu, wszystko jest niewyraźne i zlewa się ze sobą, a wspomnienia z podróży kurczą się do rozmiarów hasła 43". Podróżowanie zmienia się w powierzchowne zwiedzanie, uczta zostaje sprowadzona do pobieżnej i pospiesznej konsumpcji, a prawdziwe podróże zamieniają się w bezduszną turystykę: „W naszych czasach przeżycie przebiega zgodnie $\mathrm{z}$ szablonami $\mathrm{w}$ banalnym tempie i według przepisów rozkładu jazdy $[\ldots]^{44^{\prime \prime}}$. Márai ze smutkiem podsumowuje zmianę, jaka zaszła w samym

\footnotetext{
${ }^{40}$ Ibidem.

${ }^{41}$ Ibidem.

${ }^{42}$ K. Čapek, op. cit., s. 21.

43 S. Márai, op. cit., s. 90.

${ }^{44}$ Ibidem, 93.
} 
człowieku: „Dawny podróżnik obserwował, słuchał, widział i zapamiętywał. My już tylko jeździmy ${ }^{45}$. Świat, który jest $\mathrm{w}$ ten sposób postrzegany, przestaje być trudnym i pięknym wyzwaniem, przeżyciem totalnym i niezapomnianym, ale staje się nudny, pretensjonalny i trywialny. Świat odtworzony wyłącznie poprzez mimezis jest niepełny, bezosobowy, realistyczny, ale nierealny, bo brakuje mu interpretatora, kogoś, kto nie tylko patrzy, ale także dostrzega, aktywnie za każdym razem ożywia świat i czyni go poprzez własne doświadczanie czymś wyjątkowym, niepodrabialnym. „Napodróżować się”, według nomenklatury Máraiego, można wszędzie, żadna, nawet najnędzniejsza z pozoru trasa nie jest godna pogardy, ponieważ może stanowić doskonałą pożywkę dla wyobraźni wrażliwego podróżnika.

Obu podróżnikom towarzyszy w ich błądzeniu po peryferiach czasu i przestrzeni nostalgia, którą za Markiem Zaleskim można określić, jako rodzaj pewnej postawy wobec rzeczywistościt6 i wynika ze sposobu doświadczania przestrzeni. Jest to nostalgia za prawdziwością świata, którą można odkryć jedynie właśnie poprzez pogłębiony i otwarty kontakt ze światem i stopniowe odkrywanie jego oblicza. Przypomina to wytężone prace archeologicznet7, mające odsłonić istotę świata, przygłuszoną tonami nanosów interpretacyjnych. Odkrywanie jest także, a może przede wszystkim, przetwarzaniem owego świata zastanego poprzez filtr własnej wrażliwości, erudycji, własnego zadziwienia i własnych doświadczeń. Za każdym razem dochodzi dzięki temu do ponownego rodzenia się świata, który powstaje poprzez jednostkowe, unikatowe pojmowanie. Tym samym obaj autorzy, czując pustkę pocztówkowego świata, skonstruowanego z samych turystycznych atrakcji, przystosowanego do przeciętnych wymagań masowego turysty-widza, skrojonego na miarę uśrednionych oczekiwań, pragną poprzez dziewicze, nostalgiczne spojrzenie na pomijane i przemijające szczegóły, w których ucieleśnia się tożsamość świata, przywrócić jego niepowtarzalność. W podejściu tym dominuje nostalgia za pierwszym, żadną interpretacją niezmąconym spojrzeniem, za światem bez kiczu, za światem, który po prostu zachwyca, i to wcale nie dlatego, że ma zachwycać. Jest to oczywiście utopijna tęsknota za spojrzeniem niewinnym, nieziszczalne marzenie o pierwszym spojrzeniu. Człowiek w podróży powinien stać się świętym prostaczkiem w rękach bożych ${ }^{48}$, pozwolić się „zadrasnąć obcemu"49, otworzyć się na inny, nieznany dotąd świat, zabłądzić w czasie i przestrzeni. Dopiero wtedy będzie w stanie sformułować swoje podróżnicze kredo:

45 Ibidem, s. 90.

46 Zob. M. Zaleski, Formy pamięci: o przedstawieniu przeszłości w polskiej literaturze współczesnej. Warszawa 1996, s. 70-71.

47 Zob. E. Rybicka, op. cit., s. 485.

48 Zob. K. Čapek, op. cit., s. 36.

49 S. Márai, op. cit., s. 93. 
Gdy człowiek w końcu zrozumie, że w życiu naprawdę ciekawe jest tylko to, co ukryte za kulisami, między czwartą a piątą nad ranem w Wenecji całkowicie mu wystarcza, a kiedy mieszkańcy i turyści zaczynają się budzić, rusza w dalszą drogę albo kładzie się spać50.

Pozostaje kwestią otwartą, na ile błądzenie obu pisarzy po peryferiach czasu i przestrzeni jest dziełem przypadku, a na ile wynikiem starannie przemyślanej strategii poznawczej. Obaj pisarze instynktownie odwracali wzrok od centrum, choć wydaje się, że węgierski pisarz był bardziej konsekwentny w swoich eksploracjach peryferii. Niemniej jednak wynik błądzenia po odkrywanych na nowo nieznanych lądach znanego jest zdumiewający. W obu tekstach widać wyraźnie zaznaczone problemy, które okażą się kluczowe dla późniejszych czasów. Jest to problematyka "decentralizacji mapy", poszukiwania niewinnego spojrzenia, konfliktu masowości przeżycia i indywidualnego spojrzenia, spłycenia doznań i pogoni za prawdziwym pięknem, dewaluacji miejsc znaczących i tęsknoty za światem jako tabula rasa. Do pewnego stopnia antidotum na te problemy może być w najwyższym stopniu opanowana przez Čapka i Máraiego sztuka błądzenia.

50 Ibidem, s. 105. 